Seloka: Jurnal Pendidikan Bahasa dan Sastra Indonesia

9 (3) (2020) : $254-263$

UNNES

https://journal.unnes.ac.id/sju/index.php/seloka

\title{
Form of Hate Speech Comments on Najwa Shihab Youtube Channels in The General Election Campaign of President and Vice President of The Republic of Indonesia 2019
}

\author{
Tsalisa Yuliyanti ${ }^{\circledR}$, Subyantoro Subyantoro, Rahayu Pristiwati \\ ${ }^{1}$ Universitas Negeri Semarang, Indonesia
}

\begin{tabular}{l}
\hline Article Info \\
\hline History Articles \\
Received: \\
August 2020 \\
Accepted: \\
Oktober 2020 \\
Published: \\
December 2020 \\
\hline Keywords: \\
presidential election, \\
campaign discourse, \\
hate speech, youtube.
\end{tabular}

\begin{abstract}
Emerging and spreading hate speech online was a growing phenomenon in social media on youtube. Najwa Shihab was a youtube channel that contains shows and comments on political issues in Indonesia, one of them was the 2019 presidential election campaign. The form of hate speech in comments in the Najwa Shihab Channels was forming grammatical construction and construction of the meaning of one hate speech with other utterances. The purpose of this study was to analyze the illocutionary speech acts on hate speech and to analyze hate speech based on the rule of law in Indonesia. The analysis resulted in hate speech on the Najwa Shihab youtube channel audience comments in the General Election campaign in the discourse of the President and Vice President of the Republic of Indonesia in 2019. The approach that used in this study was a theoretical approach, namely a forensic linguistic approach by utilizing pragmatics for data analysis, and a methodological approach, namely a qualitative descriptive approach. The data on hate speech that was analyzed was a fragment of the audience's comments on two programs, namely Mata Najwa and Catatan Najwa. The results showed that there were nine forms of hate speech. Two forms of hate speech were considered to be the style of speech that was widely used by the public in delivering comments on social media. The forms of the speech were "Form of Hate Speech, Assertive Speech - Insult" and "Form of Hate Speech, Assertive Speech - Defamation". The existence of this form of speech can be a reference for the community to process opinions first before conveying it on social media. It's legally can be used as an offense in cases of hate speech.
\end{abstract}

\footnotetext{
$\bowtie$ Correspondence address:

Gedung A Kampus Pascasarjana UNNES

p-ISSN 2301-6744

J1. Kelud Utara III Semarang 50237, Indonesia

e-ISSN 2502-4493

E-mail: tsalisa.yuliyanti07@gmail.com
} 


\section{INTRODUCTION}

Communication was essentially the process of delivering messages from sender to receiver. The communication relationship between the sender and receiver was built based on the compilation of a code or language symbol by the sender rement language code or symbol by the receiver ferment Rahardjo, 2011: Communication can be controlled to enhance or support good relations with others but communication can also be used as a means of expressing expressions of hatred towards others, namely, by gathering one's preferred views and beliefs and creating groups that oppose others who do not have a point of views and interests the same one. Every human communication was in the form of information can be in the form of thoughts, ideas, intentions, feelings, and emotions directly (Cahyani \& Rokhman, 2017: $45)$.

The language was a means of communication between individuals or groups. The language was also an important part of developing culture and science (Yuliarti, et al., 2015: 79). The language was the main key to communication. The language was used by humans in everyday life such as arguing about certain phenomena in society (Fahmi \& Rustono, 2018: 29). Without language, humans would find it difficult to understand one another (Noviana, et al., 2020: 177). In this case, language played the most important part in distributing information (Supriyadi \& Zulaeha, 2017: 2). Communication events experience many problems in the community. Thus, there were also problems in language. The existence of hate speech was evidence of linguistic disorders because the function of the language used is different and was against the actual benefits of the language. George (2016: 12-13) stated that hate speech has characterized by all forms of verbal or nonverbal attacks targeting a particular person or group. It can be due to race, ethnicity, gender, religion, or sexual orientation.

Based on the 2015 Police Chief Circular, hate speech can be classified as a hate crime (hate crime). Such action has been regulated in separate legislation, namely through Circular No. SE / 6 / IX / 2015 concerning Handling Hate Speech (hate speech). The form of hate speech was in the form of insult, defamation, defamation, unpleasant actions, provoking, inciting, and spreading false news. The emergence and spread of hate speech online was a growing phenomenon. It required a collective effort to understand the meaning and consequences and to develop an effective response (Gagliardone, et al., 2015: 53).

Forensic linguistics studies linked law to language. Forensic linguistics applies linguistic theories to an event. Language has related to legal processes, both in the form of legal products, interactions in the judicial process, and interactions between individuals that result in certain legal impact. The role of language was indispensable to raise and cultivate human awareness in creating and enforcing laws (Subyantoro, 2017: 3).

Hate speech continues to expand into the digital space, and its existence has manifested in social media through groups or individuals. Nowadays, social media has become a phenomenal part of Indonesian society. One of the online social media was youtube. Youtube was a video site that provides various information in the form of videos and video descriptions. People can participate in uploading videos to the YouTube server and sharing them worldwide (Baskoro, 2009: 58). On videos on YouTube, viewers can comment on each other and rate the information they received.

One of the channels on youtube was Najwa Shihab. The Najwa Shihab channel contains many shows that discuss political issues that have developed from 2018 to 2019. Political issues in 2018-2019 coincided with the election of the President and Vice President of the Republic of Indonesia. It has caused a lot of discussion on the theme of the 2019 presidential election. The broadcast on the Najwa Shihab channel contains two programs that specifically discuss the issue, namely "Mata Najwa" and "Catatan Najwa" which were interested in watching and get a lot of responses or comments from the public. 
The political issues discussed on the Najwa Shihab youtube channel are about the discourse of the 2019 presidential and vicepresidential election campaign. Campaign discourse as a communication medium has an important role in delivering information to the public (Pristiwati, et al., 2016: 168). The election of campaign discourse has based on the phenomenon of hate speech that was often used by certain parties to bring down political opponents while attracting public sympathy during the 2019 presidential election campaign. The campaign theme featured on the Najwa Shihab channel drew a lot of positive and negative comments. Comments have been considered negatively can be included in the category of hate speech that can be analyzed both in terms of language and legal regulations.

The form of hate speech was found in comments on the Najwa Shihab channel so that it can be used to understand grammatical construction and the meaning construction of hate speech with other utterances. The form of hate speech has formed from theoretical constructs regarding types of speech acts based on Searle's theory (in Rusminto, 2010: 22-23), namely illocutionary speech acts (assertive, directive, expressive, commissive, and declarative) and categories in the legal field (insult, defamation good, defamation, unpleasant actions, provoking, inciting, spreading fake news).

Speech acts were individual symptoms that are conveyed orally in the language (Ariyanti \& Zulaeha, 2017). Meanwhile, Safrihady \& Mardikantoro (2017: 60) argue that speech acts are the product of speech under certain conditions that determine the meaningThe speech acts were carried out by speech people who have a mutual understanding with the intention of achieving certain goals.

This study was also relevant to previous research, namely from Waseem \& Hovy (2016), ElSherief, et al (2018), and Ningrum, Suryadi, Wardhana (2018). Waseem \& Hovy (2016) identified hate speech in the form of racist and sexist insults on social media. Meanwhile, ElSherief, et al. (2018) analyzed hate speech in the form of statements or assertive speech acts and in the term of contradictions that stated not, do not, no, and others. Also, another research entitled "Study of Hate Speech on Social Media" conducted by Ningrum, Suryadi, Wardhana (2018) describes forms of hate speech on social media as well as types of illocutionary speech acts on netizen comments on Facebook.

Based on these discussions, research on "the form of hate speech, comments from the YouTube channel audience of Najwa Shihab in the discourse of the 2019 General Election of the President and Vice President of the Republic of Indonesia" are appropriate.

\section{METHOD}

There were two approaches used in this research, namely the theoretical and the methodological approachesThe theoretical approach used was a forensic linguistic approach by utilizing pragmatics for data analysis, while the methodological approach used was a qualitative descriptive approach. Sudaryanto (2015) argued that descriptive research was the research carried out based on existing facts or phenomena that are empirically living in the speakers and the results of recording were in the form of data exposure.

The focus in this study was the form of speech in communication events in the form of commentary discourse contained in the Najwa Shihab youtube channel media with the theme of the presidential and vice-presidential elections of the Republic of Indonesia in 2019. The object in this research was the form of hate speech in the audience comment column on the Najwa Shihab YouTube channel, the theme of the 2019 presidential and vice-presidential election campaign discourse.

Collecting data in this study was using documentation study techniques, observation techniques, and note-taking techniques. This data collection technique can be used to obtain accurate and the validity of the research data. The validity of the data was carried out to prove whether the research carried out was truly scientific research as well as to test the data 
obtained. Test the validity of data in qualitative research includes testing, credibility, transferability, dependability, and confirmability (Sugiyono, 2017: 270).

The data analysis technique used in this study was the heuristic analysis technique and the qualitative normative analysis technique. The heuristic analysis was a process of a person's thought to interpret an indirect speech. Heuristic analysis techniques were to identify the pragmatic power of a speech by formulating hypotheses and then testing them with available data (Leech, 2016: 61).

\section{RESULTS AND DISCUSSION}

The data in this study was in the form of snippets of audience comments on the YouTube media channel Najwa Shihab which consists of two programs, namely Mata Najwa and Catatan Najwa regarding the election of president and vice president during the campaign period. The data in this study were analyzed and produced forms of hate speech. The results showed that there were nine forms of hate speech.

\section{Hate Speech Forms Assertive Speech - Insult CONTEXT: DISCUSSION ON CAMPAIGNS CONDUCTED BY} PRESIDENT AND VICE PRESIDENTS CANDIDATE RELATED TO EXPENSIVE FOOD PRICES.

P1 : "kui emak2 wowo mbok yo mikir, yen ngomong ra faham mendingan nek omah wae cuci2 piring opo klambi wae" ( ERO)

P2 : "Emak2 yg belain prawobo cebol mo jadi gundiknye kali nih... ekekekekekekek" (DP)

(data no 1)

(Mata Najwa : 8 November 2018 Jokowi vs Prabowo Ketika Harga Pangan Jadi Jualan Kampanye (Part 2))

DP (P2) in the speech expressed hate speech in the form of assertive speech acts and insulting hate speech. The assertive speech in the comments was in the form of statements delivered by P1 and P2. However, P2's speech was considered to be a form of hate speech because it was in the form of a prediction that Emak2 defending Prabowo would become a concubine (mistress). This speech was also a form of disdainful speech because it attacks the self-esteem and dignity of certain parties, namely, Emak2 was called a concubine, and Prabowo was a midget for physically attacking Prabowo was not too high.

\section{Hate Speech Forms Assertive Speech - Defamation \\ CONTEXT: DISCUSSION ON THE EMERGING OF COMMUNITY GROUP MOVEMENTS 212 \\ P1 : "Ferdinand bkin malu lg ujung2nya ngmg nyuruh ganti presiden d reuni 212 hahahaha ngakak asli ni org "ditelanjangi" abis di acara ini ngmong ga ad isinya sm skali" (TN) \\ P2 : "bacot siferdinan ngeri penjilat dulu aja selalu jelekin SBY skrg gara gara ga dipake jokowi makin ngawur aja" (RR)}

(data no 2)

(Mata Najwa : Barisan Para Mantan: Reuni 212: Gerakan Politik atau Gerakan Moral (Part 6) 6 Desember 2018)

RR (P2) in the speech expressed hate speech in the form of assertive speech acts and defamation hate speech.Tuturan asertif pada komentar tersebut berupa pernyataan yang disampaikan oleh P1 maupun P2. However, P2's speech has considered being a form of hate speech because it was a statement of opinion regarding the object. The speech included a form of hate speech defamation because of compromise with things that were not true. In this speech, it was proven by the term sycophant, tarnishing Ferdinand's goods name, and the accusation was not factual.

\section{Hate Speech Forms Assertive Speech- Unpleasant Deeds \\ CONTEXT: PRABOWO IN THE} DEBATE SAID THAT IBU PERTIWI HAS RAPED, BUT THE JOKOWI TEAM SAID THAT IBU PERTIWI WAS ACHIEVING 
P1

:"Waras gak ya ngmng diperkosa???? mulutmu harimaumu. IBU PERTIWI SEDANG BERPRESTASI๗๘" (PB)

P2 : "Seandainya Prabowo terpilih jadi presiden mungkin dia strokeeee. lalu sandi menjadi Presiden" (PP)

(data no 3)

(Mata Najwa - Jokowi atau Prabowo: Ibu Pertiwi Diperkosa atau Berprestasi? (Part 3) 12 April 2019)

PP (P2) in the speech expressed hate speech in the form of assertive speech acts and hated speech for unpleasant actions. The assertive speech in this comment was in P2's speech because it was a predictive statement proven by the word if and perhaps for the object (Prabowo). In this comment, P2 delivered an unpleasant deed aimed at Prabowo. The grammatical unit that indicates this was the clause Seandainya Prabowo terpilih jadi presiden mungkin dia strokeeee... P2 commits an act that was unpleasant to other people/other institutions both in writing.

\section{Hate Speech Forms of Directive Speech - Insult}

CONTEXT: THE DISCUSSION ABOUT ADIAN'S STATEMENT OF THE SANDIAGA UNO AND ARIEF PUYONO'S ASSESSMENT REGARDING MAARUF AMIN'S CLOSING STATEMENT

P1 :Gaji prabowo sandi di wakaf kan untuk umat, salut aku, Tp uda puluhan tahun prabowo sandi 1 persen dari bagian elit yg menguasai indonesia, mash bnyak yg di rampok puluhan tahun (ENAA)

P2 : "ngomongnya kyak sales panci wkwkwkwk TPS (TENGGELAMKAN PRABOWO $S A N D I) "(\mathrm{KL})$

P3 :"TenggeLamKan PraBowo SaNdi (TPS)" (AC)

(data no 4)

(Catatan Najwa - Nobar Debat Pilpres: Bawa Asyik Politik - Menilai Debat Final 01 vs 02 (Part 7) | 13 April 2019)

KL (P2) in the speech expressed hate speech in the form of directive speech acts and insulting hate speech. The directive speech on these comments has delivered by P2 and P3.
However, P2's speech has considered being a form of hate speech in the form of an order statement. The statement contained in the speech command "TENGGELAMKAN PRABOWO SANDI" as if ordering another party to drown Prabowo-Sandi. P2 (KL) delivered an insulting speech for attacking selfesteem or dignity regarding someone's honor, namely Prabowo, who considered his speaking style like a pot sales.

Forms of Hate Speech Directive Actions Defamation

CONTEXT: DISCUSSION ON

CAMPAIGNS CONDUCTED BY

PRESIDENT AND VICE PRESIDENT CANDIDATES RELATED TO EXPENSIVE FOOD PRICES.

P1 : "ne apa emak2 kubu bosan kok asumsinya anak2 yang kurang gizi/ztantink disuruh angkat2 ga kuat " emang rakyat dianggap kuli smuax, aku anak istrika ga pilih dia dech di dapil sumbar, dodol ne org" (AE)

P2 : "Kubu wowo ngaco mulu jgn d bohongi org kebelet pengen berkuasa" (LL)

(Data no 5)

(Mata Najwa : Jokowi vs Prabowo Ketika Harga Pangan Jadi Jualan Kampanye (Part 2) 8 November 2018)

LL (P2) in the speech expressed hate speech in the form of $\mathrm{P} 2$ 's directive speech in the comments was considered as a form of hate speech in the form of a prohibition so that Prabowo did not want to be lied to. P2 (LL) expressed hate speech, defamation because it tarnished the goods' name with things that are not true; things that are allegedly not factual, and make other people feel uncomfortable. In this speech, it was proven by the term ngaco, orang kebelet berkuasa to tarnish Prabowo's goods' name, and the accusation was not factual.

Forms of Hate Speech Directive Actions Incitement / Provocation

CONTEXT: THE DISCUSSION ABOUT ADIAN'S STATEMENT OF THE SANDIAGA UNO AND ARIEF PUYONO'S 


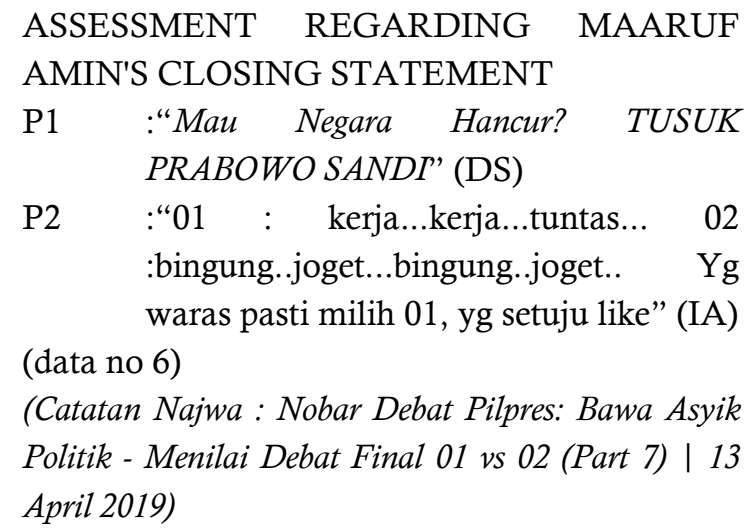

DS speech (P1) was a form of hate speech in the form of directive speech acts in the term of incitement/provocation. The directive speech in the comments was delivered by P1 which was considered as a form of hate speech in the term of incitement/provocation. The directive speech acts in the speech were in the form of recommendations. DS speakers recommend poking/stabbing the password Prabowo if you want the country to be destroyed. The speech was in the form of incitement because the speech of DS (P1) was seductive and has a function to influence the minds of the "readers" to have a viewpoint following what the speakers expect. The grammatical unit that indicates incitement/provocation towards society was the phrase TUSUK PRABOWO SANDI. Conceptually TUSUK PRABOWO SANDI means incitement to the public to stab PrabowoSandi.

Forms of Hate Speech Directive Actions Unpleasing Deeds

CONTEXT: DISCUSSING ABOUT

UNO'S DRAMA WITH HIS CAMPAIGN STYLE

P1 : "Semoga rakyat Surabaya terbuka mata ny..memilih yg benar...jgn sampai makin sengsara..." (PKP)

P2 : "Saya doakan smg wowo dan geng" nya nyungsep lagi Amiin Ya ALLAH Amiin Allohumma Amiin $Y a \quad$ Robbal Alamiin."(MD)

(data no 13)

(Mata Najwa - Tancap Gas Jelang Pentas: Di Balik Viralnya Sandiwara Uno (Part 5) 7 Februari 2019)
MD (P2) speech was a form of hate speech in the form of directive speech acts in the term of unpleasant actions. The directive's speech act was in the form of a request/hope that the Prabowo camp would get something not right. MD (P2) speakers expressed hate speech for unpleasant actions because the speakers hoped and prayed about something that could potentially cause bad things to others. Grammatically, what indicates an unpleasant act for Prabowo's camp was that in the clause saya doakan smg wowo dan geng" nya nyungsep. Conceptually, this clause means that wish Prabowo and his camp would fall in terms of political contestation in the 2019 presidential election.

\section{Hate Speech Forms Commissive Speech- Unpleasant Deeds}

CONTEXT: DISCUSSION OF THE BOTH CANDIDATES IMAGING TO GET SUPPORT FROM ISLAMIC COMMUNITY

P1 : "Berlebihan yusuf mansur memuji 01" (JS)

P2 : "Untuk Yusuf mansur@bentar lagi bisnismu akan hancur, dan kamu akan ditinggal oleh umat" (AF )

(data no 15)

(Mata Najwa : Berburu Suara Penentu: Pencitraan Demi Suara Umat? (Part 2) 14Februari 2019)

$\mathrm{AF}$ speech (P2) was a form of hate speech in the form of commissive speech acts in the term of unpleasant actions. Commissive speech acts in the utterance were in the form of threats. The speaker threatened Yusuf Mansur, which was found in the piece of Yusuf Mansur's speech, Yusuf Mansur bentar lagi bisnismu akan hancur, dan kamu akan ditinggal oleh umat, which means AF threatens verbally to Yusuf Mansyur that his business (Pay Tren) will be destroyed and left by the people. The speech was in the form of an unpleasant act because it expects someone to get something bad through verbal threats. The grammatical unit that indicates the unpleasant act of Ustad Yusuf Mansyur was the clause bisnismu akan hancur and kamu akan ditinggal oleh umat. Conceptually, a clause bisnismu akan hancur it means a threat to other 
people's living conditions and phrases kamu akan ditinggal oleh umat It can be interpreted that Yusuf Mansyur was no longer trusted by Muslims communities.

Hate Speech Forms Expressive Speech - Insult CONTEXT: ADIAN AND ARIEF PUYONO BATTLE ARGUMENTS ON DEBATE 4th PRESIDENT ELECTION

P1 : ""pak Prabowo itu orang Indonesia pangkat 2" Excuse me, WTF? (MS)

P2 : "Selamat untuk Arief Uyuhon atas ketololannya semoga lekas waras. Saya ikut menjawab pertanyaan Najwa Shihab yg menanyakan lebih Prabowo apa lebih Jokowi. Jawaban saya ya lebih Prabowo jika untuk Preciden precidenan. Tapi kalau untuk Preciden yg beneran ya sudah jelas lebih Jokowi." (SM)

P3 : "Arif musuh negara berkata sombong seperti prabowo juga" $(\mathrm{HH})$

(data no 16)

(Catatan Najwa I Debat Pilpres Tanpa Baper: Rematch Adian Napitupulu vs Arief Poyuono 31 Maret 2019)

SM (P2) in the speech expressed hate speech in the form of expressive speech acts and hate speech insults. The expressive speech was in the form of congratulations which can be seen in the clause Selamat untuk Arief uyuhono atas ketololannya. The clause was in the form of an expressive speech of congratulations regarding the bad thing addressed to Arief Poyuono. P2 (SM) expressed hate speech because speakers attacked the honor and good name of a person, either individually or communally (group), in this case, namely Arief Poyuono with the title uyuhono and ketololannya, as well as insulting
Prabowo with clause Prabowo untuk Precidenprecidenan.

Based on the percentage data with a total of 300 speeches containing hate speech, there were nine forms of hate speech. Of the nine forms of hate speech, there were two forms of hate speech that have been considered to be the style of speech that is widely used by the public in submitting comments on social media. The forms of the speech are "Form of Hate Speech, Assertive Speech - Insult" and "Form of Hate Speech, Assertive Speech - Defamation." Meanwhile, forms of hate speech that are rarely spoken by social media users are "DirectiveInsulting Actions," "Commissive Speech Actions-Unpleasing Actions," and "Expressive Speech Actions-Insult."

The results of the analysis of comments from viewers of the YouTube channel Najwa Shihab regarding the 2019 presidential election show that forms of hate speech based on speech acts and term of hate speech produce speech acts and term of hate speech, widely used by the public, especially in the youtube media.

The use of assertive illocutionary speech acts was widely used by the public when delivering comments. It was based on the number of comments that are in the form of statements in the form of opinions, objections, disagreements, notifications, affirmations, and others. Apart from assertive speech acts, there are directive speech acts that were also used by the community, including orders, advice, prohibitions, and warnings. Besides, there are speech acts that were rarely used, namely commissive speech acts that appear only in the form of threats and expressive speech acts, usually in the term of congratulations followed by the speech of hatred. 


\begin{tabular}{|l|l|l|}
\hline No & Hate Speech Form & Percentage (\%) \\
\hline 1. & Hate Speech Form of Assertive Speech - Insult & $\begin{array}{l}\text { Total } 150 \text { utterances } \\
50 \%\end{array}$ \\
\hline 2. & $\begin{array}{l}\text { Hate Speech Forms of Assertive Speech - } \\
\text { Defamation }\end{array}$ & $\begin{array}{l}\text { Total } 135 \text { utterances } \\
45 \%\end{array}$ \\
\hline 3. & $\begin{array}{l}\text { Hate Speech Forms of Assertive Speech - } \\
\text { Unpleasant Deeds }\end{array}$ & $\begin{array}{l}\text { Total }=2 \text { utterances } \\
0.7 \%\end{array}$ \\
\hline 4. & Form of Hate Speech Forms of Directive Speech - & $\begin{array}{l}\text { Total }=1 \text { utterances } \\
\text { Insult }\end{array}$ \\
\hline 5. & Hate Speech Directive Actions - Defamation & $\begin{array}{l}\text { Total }=2 \text { utterances } \\
0.7 \%\end{array}$ \\
\hline 6. & Hate Speech Form of Directive Actions - & $\begin{array}{l}\text { Total }=4 \text { t utterances } \\
1.4 \%\end{array}$ \\
\hline 7. & Incitement/Provocation & $\begin{array}{l}\text { Total }=4 \text { utterances } \\
1.4 \%\end{array}$ \\
\hline 8. & Deeds & $\begin{array}{l}\text { Total }=1 \text { utterances } \\
0.3 \%\end{array}$ \\
\hline 9. & Unte Speech Form of Commissive Speech - & Total = 1 utterances $0.3 \%$ \\
\hline
\end{tabular}

The form of hate speech that many viewers of the Najwa Shihab YouTube channel make based on the rule of law was insulting. It was because many comments are in the form of swearing by minimizing respect and maximizing insults on other parties as many as $152 / 300$ utterances or the equivalent of $50.6 \%$. The form of defamation hate speech has a total of 137/300 utterances or $45.6 \%$ that occupies the secondhighest level spoken by viewers of the Najwa Shihab YouTube channel. It was due to speeches that contain elements of tarnishing the right image or good name of other parties, causing certain parties to feel that their selfesteem was considered low, and their goods' names have destroyed.

Furthermore, unpleasant acts were a form of hate speech that was rarely spoken by viewers of the Najwa Shihab YouTube channel, with a total of 7/300 utterances or the equivalent of $2.3 \%$. An unpleasant action was classified as low in intensity because it cannot be measured by actions that are considered less acceptable to other parties. The form of hate speech with the lowest percentage was provocation/inciting as much as $4 / 300$ utterances or the equivalent of $1.3 \%$.

A suitable opinion was found in research conducted by ElSherief, et al. (2018) that states that hate speech was in the form of speech aimed at evoking action, in the form of statements or we can interpret that hate speech was in the form of assertive speech acts, and in the form of contradictions which state the word tidak, jangan, bukan, and others. The utterances which means was "I do not like talking to you $f^{*}$ ggot (faggot) and $I$ did but in a nicely

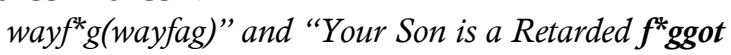
(faggot) like his Cowardly Daddy". "(I do not like talking to you faggot, and I do it but in a good way "and" Your son was fagot retarded like Coward Dad)." In the utterance there were phrases do not which means tidak suka, it can be interpreted as a statement against (contradiction). Besides, there was the word faggot who means homo, the word can be categorized as hate speech in the form of insulting another party because the speaker desires praise on the other but maximize the insults against the other party.

Ningrum (2018) also supports the results of this study through the results of her analysis regarding the form of hate speech on social media and the results in the finding that $32.63 \%$ of assertive illocutionary speech acts or the second most are forms of hate speech. It has supported by Rangkuti, et al. (2019) that researched hate speech on Facebook regarding the Batu Bara election case. Based on the results of the research conducted, it showed that ten of 
the thirteen hate speeches analyzed were assertive speech acts then directive (two utterances) and expressive (one utterance). The assertive speech acts in the study were in the form of statements and predictions.

Wiana (2020) researched hate speech during the 2019 presidential election on social media, Instagram, and Facebook. Based on the study of the analysis, insulting, and defamation were widely used on Instagram but provocation was the most form of hate speech found both on Instagram and Facebook. In the study conducted by Wikana (2020), the form of the speech was Mampus wowo kalah, gak pantas jadi presiden si wowo bacod doang gedein. Damn he's dead wowo loses, does not deserve to be the president of big-mouthed wowo, and is getting wider (Facebook, Humiliation /insulting). In these utterances, it has considered containing insults, because it took an action that maximizes insults on the other party (Prabowo) with a title wowo kalah and si wowo bacod who meet the requirements of a speech that was considered insulting.

Besides that, it found that the hate speech that emerged has dominated by the issue of SARA. Bakircioglu (2008) explained that haters do not promote freedom; rather, they advocate the persecution of weaker groups, which include homosexuals, national/racial minorities, and immigrants whom they claim superiority. Oksanen, et al, (2014) also explained that the majority $(67 \%)$ of respondents viewed hateful material online, with $21 \%$ also becoming victims of such material. Online hate material focuses primarily on sexual orientation, physical appearance, and ethnicity, and was most widely distributed on Facebook and YouTube. The authors of the study also showed a high prevalence of aggressive, hateful, and threatening social media user behavior.

\section{CONCLUSION}

The form of hate speech was seen from the use of illocutionary speech acts that are widely used by the public that was assertive in the form of an opinion, the objection, disapproval, notification, confirmation, and another directive such as orders, advice, prohibition, and warnings. Besides, speech acts that were widely used were commissive, only in the form of threats, and expressive speech acts in the form of congratulations followed by speech of hatred. Aside from illocutionary speech acts, forms of hate speech that many do was insult defamation, incitement, unpleasant acts, and defamation. It remains to be seen as a form of linguistic expressions to be used as data to support legal policy that handles cases of hate speech on social media..

\section{REFERENCES}

Ariyanti, L., \& Zulaeha, I.(2017). Tindak Tutur Ekspresif Humanis dalam Interaksi Pembelajaran di SMA Negeri 1 Batang: Analisis Wacana Kelas. Seloka:Jurnal Pendidikan Bahasa dan Sastra Indonesia, 6(2), 111-122.

Bakircioglu, Onder. (2008). Freedom of Expression and Hate Speech. Tulsa Journal of Comparative and International Law. Vol 6 (1), Hlm 1-49.

Baskoro, Adi. (2009). Panduan Praktis Searching di Internet. Jakarta: PT TransMedia.

Cahyani, D. N. dan Rokhman, F. (2017). Kesantunan Berbahasa Mahasiswa dalam Berinteraksi di Lingkungan Universitas Tidar: Kajian Sosiopragmatik. SELOKA, 6 (1) (2017): 44-52.

ElSherief, M., Kulkarni, V., Nguyen, D., Wang, W.Y., \& Belding, Elizabeth. (2018). Hate Lingo: A Target-based Linguistic Analysis of Hate Speech in Social Media. Association for the Advancement of Artificial Intelligence.

Fahmi, Resa Nurul \& Rustono. (2018). Types of Speech Acts in Indonesian Debate Argumentative Discourse. Seloka: Jurnal Pendidikan Bahasa dan Sastra Indonesia 7(1) (2018):28-37.

Gagliardone, I., Gal, D., Alves, Thiago., Martinez, Gabriela. (2015). Countering Online Hate Speech. The United Nations 
Educational, Scientific and Cultural Organization 7, place de Fontenoy, 75352 Paris 07 SP, France, UNESCO.

George , Wafula W. (2016). Social Media Forensics for Hate Speech Opinion Mining. College Of Biological And Physical Sciences School Of Computing And Informatics:University Of Nairobi.

Leech, Geoffrey. (2016). Prinsip-Prinsip Pragmatik. Terjemahan M.D.D. Oka. Jakarta: Penerbit Universitas Indonesia.

Ningrum, Dian J., Suryadi, \& Wardhana, Dian E.C. (2018). Kajian Ujaran Kebencian di Media Sosial. Jurnal Ilmiah Korpus, Volume II, Nomor III.

Noviana, Nur Rakhmi, Haryadi, Tommi Yuniawan.(2020). Types of Speech Act in the Galgil T-hirt. .Discourse: Pragmatic Study. Seloka: Jurnal Pendidikan Bahasa dan Sastra Indonesia 9(2) : Hlm 176-183.

Oksanen, A., James H., Emma H., Matti N., Pekka R. 2014. Exposure to Online Hate among Young Social Media Users, in M. Nicole Warehime (ed.) Soul of Society: A Focus on the Lives of Children and Youth (Sociological tudies of Children and Youth, Volume 18) Emerald Group Publishing Limited, pp.253-273

Pristiwati, Rahayu, R. Rustono, F. Rokhman, H.B. Mardikantoro. 2016. Metaphorical Meanings Inside of Discourse of President, Parliament, And Major National Election 2014. The Journal of Educational Development 4 (2), 167-174.

Rahardjo, Mudjia. (2011). Bahasa Sebagai Alat Komunikasi Publik dan Pembangunan Wacana. LiNGUA: Jurnal Ilmu Bahasa dan Sastra, Vol 2 (1), Hlm 59-69.

Rangkuti, Rahmadsyah, Andi Pratama, Zulfan. (2019). Hate Speech Acts: A Case in Batu Bara. Language Literacy: Journal of Linguistics, Literature and Language Teaching, Vol 3(2) : 225-233.
Rusminto, Nurlaksana Eko. (2010). Memahami Bahasa Anak-anak: Sebuah Kajian Analisis Wacana Panduan Bagi Guru, Orang Tua dan Mahasiswa Jurusan Bahasa. Bandar Lampung: Universitas Lampung.

Safrihady, S., \& Mardikantoro, H.B.(2017). Jenis dan Fungsi Pragmatis Tindak Tutur Masyarakat Melayu Dialek Sambas di Kota Singkawang. Seloka:Jurnal Pendidikan Bahasa dan Sastra Indonesia, 6(1), 59-67.

Subyantoro. (2017). Linguistik Forensik: Sebuah Pengantar. Semarang: Farishma Indonesia.

Sudaryanto. (2015). Metode dan Aneka Teknik Analisis Bahasa :Pengantar Penelitian Wahana Kebudayaan Secara Linguis. Yogyakarta: Duta Wacana University Press.

Sugiyono. (2017). Metode Penelitian Kuantitatif, Kualitatif, dan R\&D. Bandung: Alfabeta.

Supriyadi, S., \& Zulaeha, I. (2017). Dimensi Ekonomi, Politik, dan Ideologi pada Artikel-Artikel di Media Massa Cetak Jawa Pos dalam Perspektif Analisis Wacana Kritis. Seloka: Jurnal Pendidikan Bahasa dan Sastra Indonesia, 6(1), 1-14.

Surat Edaran Kepala Kepolisian Negara Republik Indonesia Nomor: SE/6/X/2015 tentang Penanganan Ujaran Kebencian (Hate Speech).

Wiana, Desri. (2019). Analysis of the use of the hate speech on social media in the case of presidential election in 2019. Journal of Applied Studies in Language, Volume 3(2), Hlm. 158-167.

Yuliarti, Rustono, \& Nuryatin, A. (2015). Tindak Tutur Direktif dalam Wacana Novel Trilogi Karya Agustinus Wibowo. SELOKA, 4 (2), Hlm 78-85. 